\title{
'Being' in Al-Azhar Park: Public Spaces in Cairo
}

\author{
Aya Nassar \\ Faculty of Economics and Political Science, Cairo University, Egypt
}

\begin{abstract}
There is a broad literature on public space and landscape and their socio-political construction, though it is not usually linked to the more contentious political theory concept of public sphere. The dual understanding of public space/sphere bears on relationships of inclusion and exclusion, where public space is seen as normatively desirable, inclusionary and offering the chances of unmediated encounters. It is important to see how far these concepts can go in understanding parks as public spaces in the setting of Cairo. The paper argues that the emergence of modern public spaces in Cairo is necessary to understand the meaning of being in parks. The paper tackles Al-Azhar park - one of the celebrated examples of recent public spaces in Cairo- as a reference to discuss the nature of emerging new public spaces in the city, with a focus on the way this space re-enforces politics of inclusion and exclusion, the nature of power relations that underlay the landscape and the social practice within it. The question of the park as a potentially politicized public space as opposed to more salient spaces of contestation in Cairo is tackled. The case of Al-Azhar park helps to problematize the notion of parks as public spaces as it gets to be applied to various contexts.
\end{abstract}

Keywords: Cairo, public space, public sphere, Al-Azhar park, modernity, contestation.

\section{INTRODUCTION}

[F]or cities in developing countries, in [this] case the Middle East, the danger is not from external forces (also known as orientalists, colonialists, imperialists, etc.) but from the inside, since local decision-makers view the general public as a threat that has to be dealt with and contained. In doing that a large segment of the population is precluded from certain rights (such as enjoyment of outdoor activities and socializing in urban historic areas) [1, p. 297].

The quote is from a recent study by Elsheshtawy on urban transformation and social control. It expresses the complexity of dynamics that are usually at work to shape the right of being in public spaces in the Middle Eastern city. At the center of these dynamics, is how the 'general public' is viewed as a threat to be contained rather than a rightful user of public space. This paper deals with the case of Al-Azhar park, which is rather different than the case, Elsheshtawy worked on in his study. I want to use Al-Azhar park as a reference point to discuss the nature of emerging new public spaces in Cairo. Especially, how exclusionary they could be, even as they present themselves as open and inclusionary. In this paper I depend on theoretical literature that deals with concepts of public space and the political relations inherent in it, this body of literature is not specific to the Middle East. It is a theoretical concern to see how far these concepts can help in understanding a Middle Eastern urban setting. The paper also tries to engage with a growing body of literature

*Address correspondence to this author at the Faculty of Economics and Political Science, Cairo University, Egypt; E-mail: ayanassar@feps.edu.eg that seeks to deconstruct the meta narratives that frame Cairo, and its public spaces.

Cairo as a field or object of study is dominated by several contending discourses. Singerman and Amar [2] argue that it has its own body of literature and its own meta-narratives. The two groupings of legends they pose are the image of the bomb and the image of the tomb. The myth of the bomb is the widespread image among circles of political scientists and journalists where Cairo is a social bomb of expanding slums, terrorism, crime, poverty and insecurity, and that it is about to explode. This narrative helps in promoting a 'particular landscape of perverse economic liberalization (producing gates, walls, mass arrests and surveillance systems)' [2, p.21]. The second image of the tomb poses Cairo as a city of the dead, as a passive open museum, and a historical landscape of monuments, and oriental architecture. These images are particularly interesting, since the case study of this paper, Al-Azhar park is juxtaposed exactly between the icons central to these meta narratives. The famous 'city of the dead' is located exactly to the east of the park, and the skyline view shows cemetery zones, two highways cutting through the city of the dead and an informal housing area (see Fig. 1). To the west is Al-Darb Al-Ahmar neighborhood. It is a historical but deteriorated area that has monumental value, and was a hub of drug dealing before a police crackdown in the 1980s. The westward skyline as viewed from the park catches glimpses of the neighborhood, a panoramic view of the domes, minarets and other monuments in the area and distant 'internationalist', all-glass business buildings and hotels (see Fig. 2). The park is also very close to the Al-Azhar and Khan Al-Khalili area, a religious and touristic hub in Cairo that has witnessed bombing incidents in 2005 . Hence, the park offers a bird's eye view of the very images of the tomb and the 


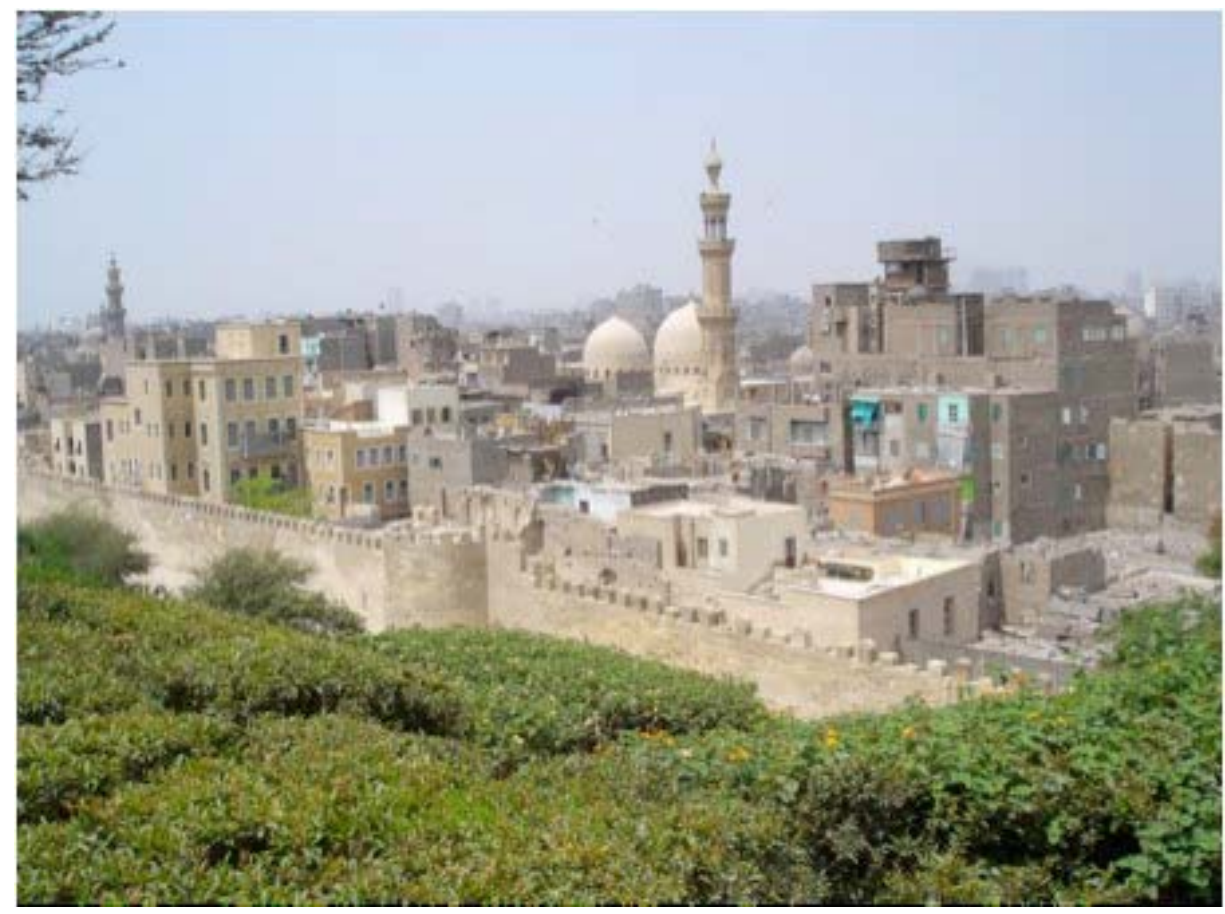

Fig. (1). West view of Al-Azhar park (photograph by Aya Nassar).

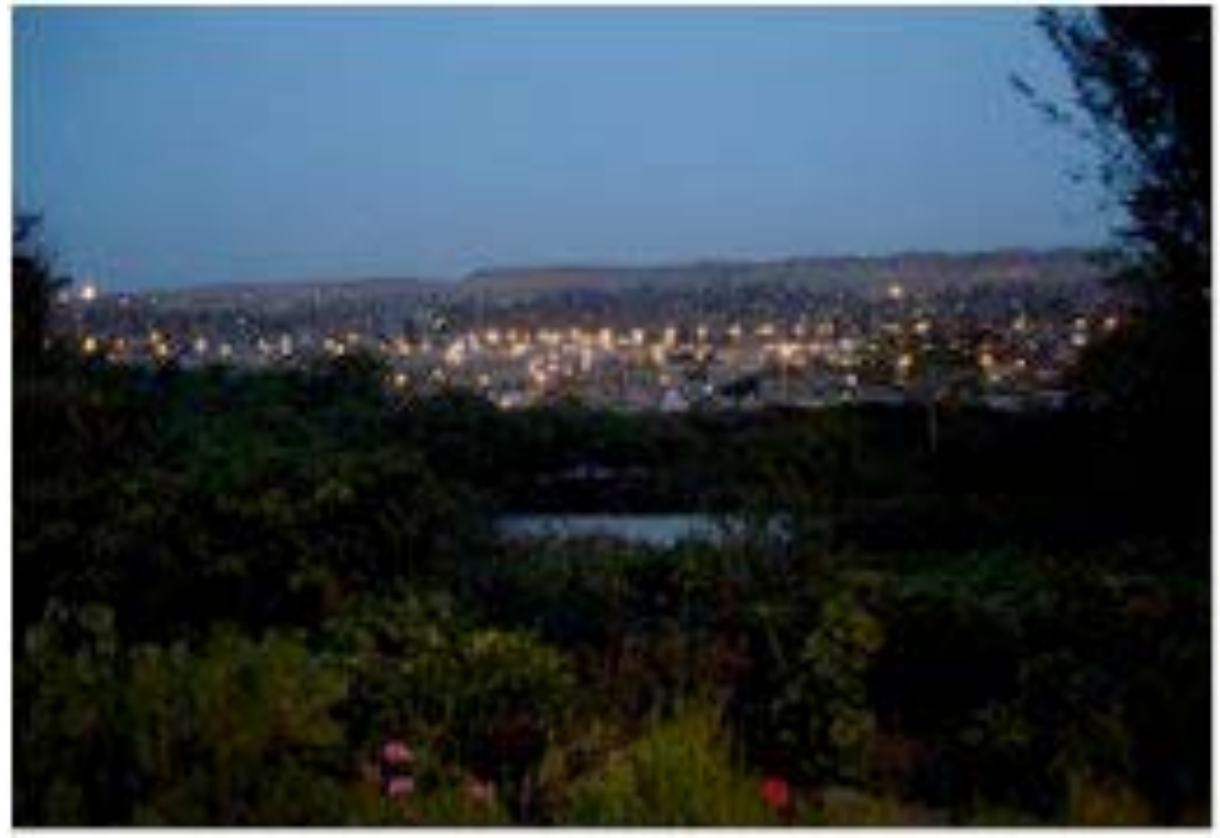

Fig. (2). East view of Al-Azhar park (photograph by Aya Nassar).

bomb in a complex multilayered visual superimposition that offers something different for everyone depending on what they are there to see.

The case of Al-Azhar park, might have complex dynamics in its making as a public space. Local decisionmakers play a role, as well as dynamics of external financing, local and global expertise, the multi-use of the project, economics of sustainability of the park as well as the developmental ambition that links it to the neighboring A1Darb Al-Ahmar. The park is celebrated as one of the most successful projects for public spaces [e.g. 3], while it raises the debate of whether or not it should be considered as public space at all. The paper seeks to politicize the debate about belonging to public space by linking it into the contentious political theory concept of public sphere. It also seeks to problematize the notion of parks as public spaces as it comes to be used comparatively through different contexts. First, I do so by taking into consideration the engagement of 'public space' with the more political-theory laden concept of 'public sphere'. In this section I discuss the normative ideal of the concept of public sphere and the theoretical tensions it has with actual public spaces. Secondly, I discuss the historical context of the emergence of 'modern' public spaces in Cairo, which I argue shapes the meaning of being 
in public space. Then I move on to the specific case of AlAzhar park, with a focus on the way this space re-enforces politics of inclusion and exclusion, the nature of power relations that underlay the social practice within it, and lastly the question of the park as a potentially politicized public space as opposed to more salient and obvious spaces of political contestation in Cairo like Tahrir square for example.

\section{PUBLIC SPACE AND PUBLIC SPHERE}

The concept of public space entails a theoretical paradox. In terms of political and social theory it refers to abstract Public Space/Sphere, while in urban studies it more appropriately refers to specific actual public spaces/places. This duality was highlighted by Don Mitchell [4], and it is relevant in so far as it bears on the dynamics of inclusion and exclusion. Two key theorists - Hannah Arendt and Jürgen Habermas- have pondered upon the concept of public space/sphere as it stands in current usage [5, 6]. Arendt refers to the Greek Polis for the normative ideal of "public space'. For her, a public space is the space of appearance that is created when people come together joined by speech and action, it is hence a space of civic virtue and the practice of politics. She laments the loss of the public space in which one speaks and acts freely and equally, to the rise of a social realm that accompanied the modern transformations and the rise of mass societies [5, 7]. The Arendtian conception of public space hence is a normative ideal. Public space is unlike material spaces because

\begin{abstract}
'...it does not survive the actuality of the movement which brought it into being, but disappears not only with the dispersal of men...but with the disappearance or arrest of the activities themselves. Wherever people gather together, it is potentially there, but only potentially, not necessarily and not forever' [5, p. 199].
\end{abstract}

For Arendt it is a space of freedom, plurality and equality. It is that which preludes the existence of politics and that within which politics is practiced. Nevertheless, it is to be noted that it is a space that was historically made possible only by a homogenous and exclusive community. There are common critiques to the model of the Polis from which Arendt draws her conception. The public space of appearance that Arendt describes was exclusionary, and it was only made possible by excluding slaves, women and foreigners $[5,7,8]$. Actually Arendt does not ignore this, but for her this exclusion is precisely there because of the unique understanding of the public/private divide held at the time [5].

The Habermesian concept of public sphere draws on this Arendtian conception. Habermas, though, would concern himself with the rise and transformation of the bourgeois public sphere during 17 th and 18th century Europe. For Habermas, the public sphere is where private selves come together to discuss public affairs. It is public as long as it is accessible to anyone and inclusive in principle [6]. Again the problem with this model of public sphere is that it was never accessible to all, again the theorization of the concept stems for actual spaces of coffee houses, and clubs that were never accessible to all [9]. Habermas concerns himself with the rise of the bourgeois public sphere that differentiates itself from a plebian public sphere, even though it adopts a discourse of moral responsibility of those not included [6].

For both Arendt and Habermas, public space/ sphere holds the normative ideals of freedom, plurality, equality and inclusiveness. But in fact the actual public spaces they theorized from were socially exclusive in practice, and their cohesion was lost and disrupted with the loss of this social exclusivity. I argue -along with Mitchell - that this paradox of inclusion and exclusion in public space is due to theoretical tension between public space/ sphere as a discursive political sphere that acts as a normative ideal of inclusion, and real public spaces that are differential and are always subject to contestation and claims of order $[4,10]$. Nevertheless as Mitchell argues, the normative ideal of inclusion that embeds the concept of public sphere can become 'a rallying point for successive waves of political activity.' [4, p. 117] and hence it should not be readily discarded. As an inspiring normative ideal, the political public sphere would regard public spaces as spaces of freedom. Like cities they pose the normative ideal for politics and public life; which fits the traditionally romanticized representation of cities as spaces of freedom and the practice of citizenship [11, 12].

Contemporary political theory would still concern itself with the normative ideal of public space, but with sensitivity to the differential nature inherent in it. Iris Marion Young argues that publicity is one of the virtues for a normative ideal of city life. While several political theorists would argue for a public as a realm for consensus or unity, she believes that our experience with public space teaches us differently. A public space is a place accessible to everyone, everyone can participate and enter, and while doing so everyone takes the chance of encountering difference. The city offers these public spaces like parks, streets and plazas, where people get to encounter each other, and it is in them that group diversity is witnessed, and city life gains its excitement and vitality. These public embodied spaces and the ideal of inclusion they express are important for a democratic life, in as much as they bring strangers and different people within fields of visibility and encounter [13, 14].

Nevertheless, real public spaces do not always fit this normative ideal, especially with the increasing rise in the tendency to create walled and gated communities, places of leisure, and of residence. They could include public or semipublic spaces like parks but the nature of openness becomes contested, as Young notes, 'Some walled enclaves encourage community among their residents; thus they are not entirely private spaces. But their purpose is to insulate residents from the surrounding city, its people, and its problems.' [14, p.212]. With the quest for cleanliness, safety and order the very well-to-do as well as segments of the middle class can segregate themselves from disorder and annoyance of a complex urban fabric. They can avoid fear of crime, and encounters with the less well off and their lifestyle while residing in privileged enclaves. This limits encounters and eventually de-sensitizes the well off towards the problems of the less well-off who could be residing just on the other side of the wall/fence/gate $[10,14]$. These semi-public spaces relate to what Bickford calls 'tamed public space'. Tamed public space though does not mean the same for everyone, 
and the experience of being in public differs according to how we experience 'others', which is in turn mediated by media stereotypes [10]. The architectural design could exhibit

'antipolitical impulses toward exclusion, control, security, sameness, and predictabilityyet often under the guise of public space. One is tempted to say that what these phenomena share is that they are material and architectural constructions that obscure the presence of differences and inequality in the polity and create a tamed and prettified version of public space.' [10, p. 362].

Tamed public space comes to exist through surveillance mechanisms, policing guards, different forms of gating and fencing, or even making the places uncomfortable to be in. This process of gating or boundary making doesn't mean the same for everyone, a security guard can be a reason for assurance to some, while threatening to others, and hence these symbols of fencing acquire different social meanings to different people. Their danger, she argues, is when we become so used to these walls that we forget they exist and get accustomed to the idea that the world consists of those we see inside these spaces [10]. Sprinkler systems, benches that make it impossible to lie down and the like, create uncomfortable places that could serve to subtly filter the kind of acceptable and preferable actions in public spaces, and to incite different meanings with regards to who has the right to belong. Moreover public spaces can also create their own relationships of power with the way they are landscaped to become an object of 'visual consumption' [15], a view to see rather than a place to be in, and where 'every interaction is carefully planned', and where images of contact replace actual contact, and where the undesirables are excluded [4, pp. 119-120].

In addition to this tension between an inclusionary normative ideal of a public sphere, and exclusionary differential actual spaces; contestations also occur on the values that a public space should embody. While the normative ideal would emphasize inclusion, freedom, absence of coercion and plurality, a key question is who is the 'public' that gets to enjoy these values. The existence of surveillance measures along with other codes that permit or prohibit certain actions, make public spaces contested, as spaces with tendencies of order and discipline versus spaces of open inclusion for all [16]. Under the pre-text of freedom, a public space could be a space of free, unmediated interaction and absence of coercion, and hence it will be highly politicized and tolerant to disorder, or alternatively it could be a place free and open for recreation and entertainment to be used by an appropriate public that needs safety and order. Mitchell argues that the 'public' nature of any public space stems from this contestation between these two visions [4]. As will be shown later, with these terms, the case of Al-Azhar park, represents at first glance a clear example of the recreational, ordered and controlled space, and in these terms it is hardly politicized. Mitchell explains, in addition, that public spaces should also act as spaces of representation for political organizations and address a larger public [4]. In this sense, Al-Azhar park couldn't generally fit as a space for political representation, had it not been for a couple of some very recent political events that it witnessed.

To conclude this theoretical discussion the 'public' is seen as normatively desirable in itself. Public parks represent key public spaces in as much as they offer spaces of unmediated encounters. In the case of Cairo though, the history of modern parks affects their openness to an undifferentiated public. Therefore in the next section I discuss the emergence of parks in modern Cairo, which shapes the meaning of being in a public park in the Middle Eastern metropolis.

\section{CAIRO’S ‘MODERN’ PUBLIC SPACES}

It is usually argued that the notion of public spaces in Cairo witnessed its major transformation in the $19^{\text {th }}$ century to accommodate the new rising urban identity [17]. Prior to the $19^{\text {th }}$ century the distinction between the public and the private was not a fixed boundary; rather there were degrees of accessibility that shifted according to the practices, the time and the persons involved [18].

Cairo's modern urbanization schemes usually date back to the vision of Khedive ${ }^{1}$ Ismail (though it could be argued that it started earlier). In 1867 Ismail visited the universal exhibition in Paris to inaugurate the Egyptian exhibit. He was personally received by Haussmann, who showed him around a very altered Paris. Janet Abu-Lughod points out that it is possible that on that visit Ismail met BrailletDeschamps the landscape gardener who had executed the plans for the Bois De Boulogne. It is also possible that it was then when he first envisioned creating a modern formal garden of Al-Azbakeiyah replacing a pond. Upon his return to Cairo Ismail had set his heart on planning the opening of the Suez Canal with a massive celebration parallel to the exhibition. 'Cairo must be cleaned, polished, and given at least a façade of respectability '[19, p. 105], comments AbuLughod. Thus Barillet-Deschamps was engaged in Ismail's plan to modernize and beautify Cairo. At the center of this 'polishing' project was the Azbakeiyah park. It had a preliminary unimaginative design, and hence BarilletDeschamps was commissioned to redesign it as a $19^{\text {th }}$ century French garden, a plan that was complete by the time the guests arrived to the grand opening of the Suez canal. Barillet-Deschamps remained in service even after the urbanizing projects relaxed after the opening. His schemes included covering the whole Island of Al-Jazirah with a formal park surrounding Ismail's palace, and a five and a half miles long and three miles wide park to cover the western bank of the Nile which he died before completing, and which later became the current zoo, and the campus of Cairo University [19].

The $19^{\text {th }}$ century urban spaces, like Azbakeiyah park, that were the focus of Ismail's plans to modernize Cairo became the hub of public and social life. But this public life didn't include all different groups of people, as Ahmed would argue [17]. Locals were confined to the old quarters and came to the vicinity of Azbakeiyah to entertain and perform, i.e. as role players in a theatric scene. She further concludes that the construction of public spaces was dominated by elite and foreigners in accordance to their preferences and the

${ }^{1}$ Khedive was the official title of Ismail Pasha and his successors till 1914. 
space was regulated and controlled hence producing contrasting narratives [17]. Other examples of Cairo's celebrated $19^{\text {th }}$ century parks show the same tendency, for example the Giza Zoo evolved out of the Khedive Ismail's harem and was intended as an open area for bourgeois promenades [20]. What is also common is how the parks were created to represent notions of modernism, sterilization and hygiene and respectability. The Azbakeiyah park for example was created with notions of sterilization in mind, since it was out of hygiene that the pond that was in its place was to be cleansed. In addition to that, the objectives of creating a respectable leisure place as an alternative to the nearby pleasure gardens of cafés and prostitution were in mind. Battesti reflects that this coincided with the modern global meta-narrative of morale, modernity and hygiene that guided creating parks in urban settings elsewhere [20].

Of course, in the case of these 'modern' parks the colonial design of the public space was later appropriated by popular classes as wealthier classes opted for more exclusive 'public' places [20]. Writing in 1971 Abu-Lughod recounts the story of decline of Al-Azbakeiyah park, from an 'exclusive domain, fenced and with an admission charge, in which white uniformed nannies paraded pampered babies, to which Europeans and those with European pretentions flocked to listen to military band concerts.' [19, p.209 emphasis added] to a sad deterioration where the fences have been removed, the admission charge long gone, and where the garden is not maintained, and where families picnic as they please littering the grounds with their leftovers, in a park stuck in Cairo traffic and open only for few hours a day [19]. Not all the parks of the $19^{\text {th }}$ century got along that same road of perceived decline associated with openness, for example a part of the gardens around Ismail's palace became an elite sporting club, which is now Al-Jazirah club with a closed membership, while another part became open to the public as an aquarium and park [19].

The history behind designing the parks poses the question of whether they were public at all in the first place. They definitely were not conceived as public spaces of inclusion of all, rather sterilized, clean areas of leisure and promenade, designed to cater for an urban bourgeoisie and a European 'public'. These places were kept picturesque and visually dramatic, and kept functioning as long as they retained their element of social exclusivity. Opening these places to the public was generally accompanied by their decline, decay and lack of maintenance. This in turn, drives the well to-do upper and middle classes to seek other more exclusive 'public' spaces, like social and sporting clubs with closed membership, or the contemporary trending cosmopolitan experiences of shopping malls [21], and western styled cafés [22] that cater for the aspiration of a younger generation of an affluent, and cosmopolitan oriented middle class, or lastly the privatization of public places for the sake of social control [1]. All of these are examples which show that the tendency for creating tamed public spaces that highlight social stratification and difference, continue to have its thrust decades later with the neo-liberal moment. Similarly, the high modernist appeal to moral and hygiene cleanliness associated with public parks have not receded. Recently, the same concern was underlying the design of Sayyida Zeinab Model park. A key objective was to transform the park from its former status of being 'the nighttime meeting place for drug users, gangsters and alcoholics' [23, p. 42] to become a national center for children's culture.

The discussion of evolving parks in $19^{\text {th }}$ century Cairo, helps us better understand a historical practice and experience of 'being' in parks as a form of being in public space that is nevertheless tamed, recreational, picturesque, and exclusionary. This stands in opposition to a free space of encountering difference. This experience also informs discourses of lamentation of parks as public spaces of a golden age, as they became deteriorated by appropriation and inclusiveness. I argue that without highlighting this particular historical experience it is difficult to contextualize visions of the more contemporary project of Al-Azhar Park.

\section{BEING IN AL-AZHAR PARK}

The conception of Al-Azhar park coincides with the same notions of dramatic landscaping, a mission of civilizing the neighborhood, literal sterilization, morality, respectability and cleanliness. All of these are innocent motifs in representing the park, but carry class overtones. One example of reporting the creation of the park went in these terms:
'Not since the days of the Khedives back before Garden City lost its gardens, Opera Square lost its opera and Orman gardens became a zoo divided has a public park of this size appeared in the city proper. Like its predecessors, Al-Azhar Park was made possible by the generosity of an extremely wealthy philanthropist. Unlike the others, it will be a park for the people part of a larger effort to revitalize the once impoverished community of Darb Al-Ahmar. Perhaps even more importantly, it will earn its keep. The park is expected to attract 2000 visitors a day and be self-sustaining within two or three years' [24].

The reference to the days of the Khedives brings into mind the golden age of modernization of Cairo, and the $19^{\text {th }}$ century parks that were discussed earlier. It also situates the relatively new project of Al-Azhar park within the same discourse that evolved around its $19^{\text {th }}$ century predecessors. The idea to create Al-Azhar park dates back to 1984, and it is part of a project run by the Agha Khan Trust for Culture. The area on which Al-Azhar park exists now used to be historically a dumpsite. It is adjacent to Al-Darb Al-Ahmar area, which is a poor, historically deteriorating popular area that is rich in Islamic monuments at the same time. The project took upon itself the construction of three water tanks for the population of Cairo and replacing the dumpsite with a green space, and a socio-economic rehabilitation of Al-Darb Al-Ahmar neighbourhood [25]. The park prizes itself as the green lung of Cairo, and the project proudly claims to have altered the landscape of the city.

\section{Inclusion/Exclusion in the Park}

As most parks in Cairo, Al-Azhar park is fenced and entrance is with a ticket, despite the fact that park was created with an initial vision of it being open to all social classes [26, p.217]. When wondering around the park one 
notices shifts in different groupings of people one would encounter. Inside the park there are usually a lot of nonEgyptians, wandering tourists photographing the scenes, others more intrigued by the view from above and the access to the very different and perhaps more 'authentic' popular area that contrasts sharply with the park's organized and spacious landscape. The entrance will be crowded with families, or couples who are just enjoying 'being' in a park or playing with or bathing in fountains (see Fig. 3). Visitors from middle and upper class usually frequent one of the upmarket restaurants in the park, and younger visitors with a cosmopolitan outlook target the Geneina theatre.

It might not be unusual to see young people descending towards the theatre and one of the security guards carefully watching over them and preventing another group of young men from following them. Subtly the guards of the park informally shape the kind of people to access specific areas in the park, and help maintain it 'clear' and 'safe'. Hence, while the park truly offers different activities for different classes of people, it is questionable if it brings different people together to belong to the same space, rather than bringing different circles in distant visibility and juxtaposition. Most of the interviews I did were with university students and graduates, who are economically well to do, who speak English fluently and would represent middle class. In an interview conducted in the lake side café -one of the three main restaurants located in the park- a young woman reflected on what attracts her to the place: 'I like that the park suits different styles, like you have Trianon [a Western styled café located inside the park], or if your life-style is less affordable you can just sit on the benches.' As I probed her into looking around the place we were in and pointed to the faraway benches barely seen from afar, I said 'like those way over there?' she replied, 'Okay you are right, they are not exactly combined'. This sort of differences within the park is striking if you wander through it, and it is obviously understood that there are different kinds of visitors, and that the space offers different functions for different groups of people.

An example is the aforementioned Geneina theatre. This theatre is a cultural venue within the park, run by Culture Resource (Al Mawred Al Thaqafy), which is a regional nonprofit organization that seeks to support independent artists in the Arab region, among its many other objectives. In an interview with Ashraf Kenawy [May 25, 2011], the manager of Egypt's Programs and the theatre in the organization mentioned:

'I do not chose my audience, nevertheless, my audience is of a special nature, some are the park's visitors, usually about $20 \%$, you can notice them, sometimes they leave in the middle of the concert, others are the audience and fans of the program of El-Geneina itself, and the rest are usually the fans of the specific band playing...the expansion and diversification of audience can happen depending on the show, a unique example was in October 2010 when we held the international circus festival, the audience was very diverse, social wise and age wise, it was great, and it attracted mostly the park's visitors.'

For him though, the integration of the theatre and its relationship to the park is not very relevant to how the theatre operates, and the audience it should attract.

\section{The Park's Accessibility}

The theatre lies at the area next to the historical Ayyubid wall that is under restoration. The wall was unearthed while

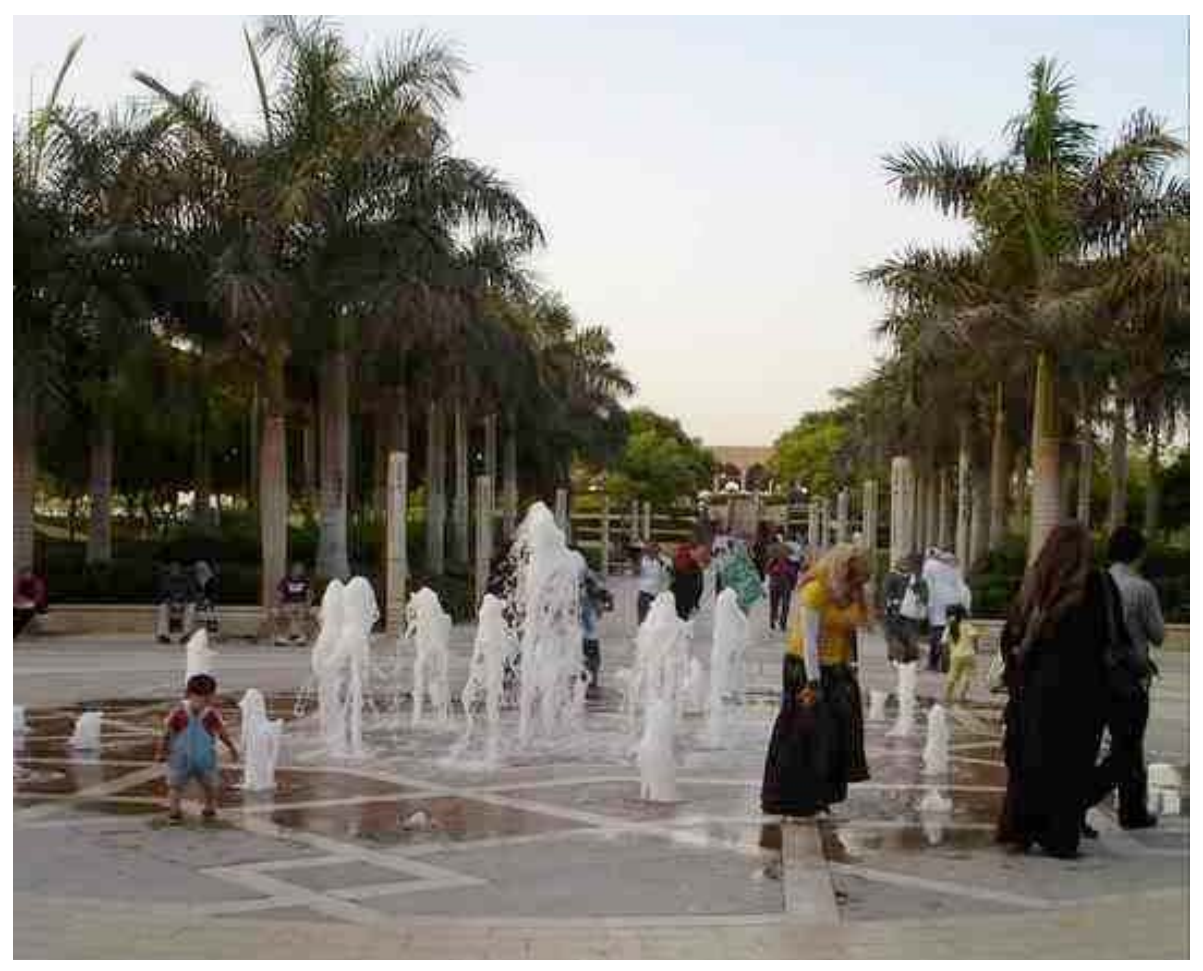

Fig. (3). The entrance of the park (photograph by Aya Nassar). 
clearing up the dumpsite, and it separates/connects the park to the adjacent area of Al-Darb Al-Ahmar. The park is supposed to work with a notion of permeability in relation to the neighborhood. That is evident in its perceived role and relationship to the community. The park prizes itself on being close to it, and it sees itself as a catalyst for development in the neighborhood. Thus, its initial vision is to create a public space for people, while working on their heritage, and social and economic conditions. The wall has a separate gate for entrance to or from the area. In the beginning this gate to Al-Darb Al-Ahmar wasn't very much promoted, and depended on people's curiosity to ask the guards, because it is significantly smaller and less conspicuous than the main entrance. A lot of people I spoke to wouldn't know before hand that the park has an access to the Al-Darb Al-Ahmar area, for example. Thus, the open connection to the neighborhood might be left untapped because of lack of willingness and curiosity to venture in. In some of my visits though, I noticed that there are some deterring signs as well, like security guards asking you where are you going, or no-pass cones (Fig. 4).

Fig. (4) shows the beginning of the stairway down to the promenade by the Ayyubid wall that is being restored and that offers an access to the community of Al-Darb Al-Ahmar from the park. The picture was taken on one of my earlier visits. By the second visit the do not pass cones were removed, instead there was a guard. The guard allowed us after some negotiation and pretended naivety on our part to descend the stairway that leads to the historic promenade and take a stroll, we had to negotiate our way for a while after several 'it's prohibited' (mamnou) on his part, and insistently asking to see the gate and promising it won't take more than five minutes. Only half-way through the staircase we heard another 'it's prohibited' from a guard below, and again after negotiations we were allowed to take a stroll after promising not to take pictures. It is worthy of note, that formally it is not prohibited at all for the public to access this area or to use the gate. In fact the park's administration organizes guided tours along this promenade. On a later visit, I used the structured guided tour, and the experience was different, where a mini-golf car takes a visitor to the beginning of the wall, posing at the midway gate. This interplay between what is formally allowed and what informally shifts between freedom and prohibition creates a practice of constant negotiation, with guards as well with signs and maps, about where one belongs in the park and how to 'be' in it.

Fencing and access granting is again constitutive to the nature of 'publicness' of the park, as I have tried to show. As Susan Bickford would argue, gates could take a variety of forms, impenetrable walls, barbed wires, redlines on a map [10] or even do not approach, or caution tapes. And these could have different social meanings to different people, and help construct difference and regulate encounters. The presence of a guard along a path could be reassuring for some, threatening or discouraging for some, and provocative for others.

The nature of openness and inclusion also relates to access to the park, in addition to random encounters inside it. Deciding on whether the park is truly a public place or not is rather complex. An argument for its public nature runs along the lines of it is more public than social clubs with closed memberships, so it is considered as a public park in this sense. In the light of the historic experience of modern parks in Cairo discussed earlier, it can be inferred that a priced and fenced park wouldn't be considered unusual, as it would be in other contexts. Pricing also is not a fixed boundary since prices shift from weekdays, weekends and public holidays,

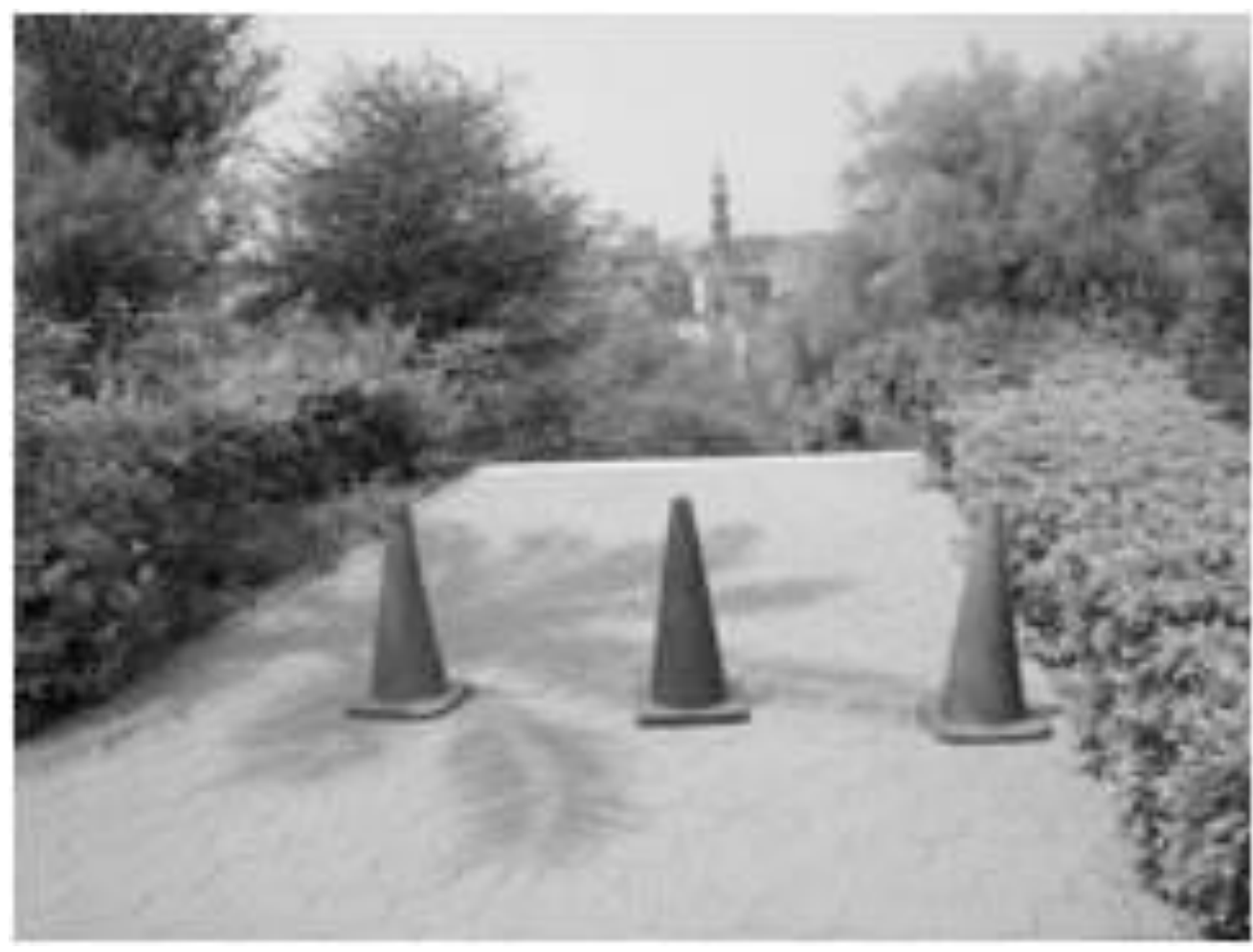

Fig. (4). Staircase to the historic wall (photograph by Aya Nassar). 
special prices are granted for families, and reduced tickets are there for children. Another 'category' on the pricing list is people from Al-Darb Al-Ahmar and Al-Gamleyya, who can enter on a reduced ticket. But the main function of pricing among some of the park frequenters I have spoken to is to act as a safeguard for the park to stay clean, and to control the numbers to avoid crowdedness. For many of those I have talked with, if it is left open to all it will get spoiled and crowded. None of those interviewed would resort to class-related terms. Issues of concern will always be security, space and cleanliness. The term clean in recent vernacular use refers to upper-class connotations, as opposed to vulgar, crowded lower-class places or style of dress. This coincides with the literature on dirt and cleanliness as classificatory and policing systems, and metaphors of boundaries [27]. Things that would annoy conservative young visitors are the unrespectable practices that young couples would engage in secluded places. Nevertheless the park is still some place respectable for them since it is spacious, so one can avoid unpleasant encounters and because of the role of security. For one of the girls I interviewed it is one of the places that her parents will feel comfortable in allowing her to go, since it still fits into an image of respectability and cleanliness.

These concerns reflect what Battesti noticed while conducting interviews for his studies on the zoo, he notes that:

'Criticism of the public gardens is often severe among representatives of the wealthier strata of society who express regret about the 'invasion' of public spaces by the masses who 'do not know how to act, who are not respectable' (Mu'addab) [20, p. 503].

\section{Contestation in the Park}

The park might be the new 'it' romantic place for young couples. Both Elsheshtawy and Batettesti take note of the opportunities public spaces open up for young unmarried couples or harmless teenage flirtations. Elsheshtawy in particular reflects on the changing gender relationships as one of the elements of urban subcultures that public places respond to. While it is traditionally unacceptable for a young unmarried couple to appear together in public, public spaces allow the room for them to become a not unusual sight in Cairo, since they are not the exclusive domain of men like the traditional café but instead integrate both men and women in their environs [1].

Security guards, though, do keep an eye on what would be unacceptable behaviour, to keep 'the reputation' of the park, and sometimes they would regard it their role to check any inappropriate behaviour even if not in a direct or confrontational way. Such regulation often induces reaction either subtly or confrontationally. After sunset a security guard could exclaim that sitting on the grass was forbidden as the sprinklers were about to work, directing his note to young couple. In one of the instances the young man made sure to throw the same comment to another guard sitting on the grass along the way...'it's not allowed to sit on the grass, the sprinklers are going to start'. Though guards have authority, they would resort to informal perhaps hidden ways of controlling 'the places to be' in the park and visitors would react sometimes by forms of hidden dissent. Some times these informal negotiations could turn into confrontational contestations. One of these incidents of a direct confrontation between security personnel in the park and a young couple, got filmed and uploaded on Youtube, raising a small debate about infringing of personal freedoms and what could constitute as moral or appropriate behaviour/discipline in a public place. Having seen the Youtube video, it did not seem to raise a huge controversy then [28]. Yet, it indicates that efforts to police and control the park will not always go uncontested.

Contestation also strongly features in disputes between security and the cultural theatre in the park. Although the park's administration is fairly neutral, the theatre has been subject to conflict with authorities. In 2006, a concert that was supposed to feature a famous dissident poet was banned and the theatre had to stop performances [29]. Reasons given were related to security and safety measures of the theatre, while Ashraf Kenawy brought it back to the security mentality that infiltrates cultural production, and that have been generally hostile to independent cultural production. 'The Security mentality sees the theatre and its audience as dissident and anti-regime, the ironic thing is that I still get this after the whole political regime has been brought down', he commented. The theatre was back in business after six months thanks to media pressure, but Kenawy said he still had a problem with the security mentality of censorship. He depended on the support of the audience that has grown and come to respect the theatre. The theatre also helped in expressing controversies in the cultural scene post January $25^{\text {th }}, 2011$. In October 2011 the theatre organized a concert for Shaa'by (popular) music, where DJs express the voice of the art scene of informal areas, slums, and the poorest young in urban Cairo [30]. The concert stirred interesting debate on the event's page on Facebook that got to be articulated in terms of class, propriety, morality and value of high culture.

\section{CONCLUSION: THE PARK AS A POLITICIZED PUBLIC SPACE?}

With 2011, the academic and political interest in public space and its appropriation surged, with images of Tahrir square and political protests that claimed public space and enforced political change. Attention was diverted from less contentious public spaces, and possibilities of chance encounters and politics and modes of belonging there. As has been argued earlier, the nature of public space stems out of the contending visions of its designated use, its tolerance to disorder and difference, and for offering space for different people to belong. The political concept of public sphere/space poses a normative ideal of freedom and inclusion; nevertheless the paper has discussed how the theoretical concept entails a paradoxical relationship of exclusion that is brought to light when encountered with actual public spaces.

Al-Azhar park in general represents a place for an 'outing': the middle-class term that came to replace the term 'Fosha' that usually denoted going out for leisure. In this sense the park corresponds to a recreational place, and a dramatic visual landscape that has multiple layers in a dense historical urban fabric. For some of those I spoke to, (mainly middle-class young people) order and social discipline is 
guaranteed by the presence of security and is important to maintain the park as a 'friendly' public space. For others, like the theatre manager, the presence of security is pointless and absurd. 'Why have security inside a park? What could be dangerous inside the park?'

I would, thus, argue that with more encounters among different groups that frequent the park, contestation could begin to rise to about the values the park should reflect. So far the park is still a 'tamed public space', but one that is also used for events of political representation. After 2011, two newly formed political grouping chose to launch the inaugural ceremonies in it, which has not been a very common practice before. It was chosen to launch a newly formed political party, Al'Adl. In a phone call, Mustafa AlNaggar one of the founding members explained the reason why they chose the place:

'We wanted to deliver the message that we combine authenticity and modernity, as youth we do not want to be divorced from our identity, we chose Al-Azhar park to stress this idea, we also chose the place inside the park that has the background of mosques and the citadel, we wanted this to be the background...secondly, people are used to inauguration ceremonies that are in Hotels, or syndicates, we wanted to reach out to people in a place where they would normally frequent'.

Two concerns appear here. The first is the symbolic landscape that the park conveys by its juxtaposition to popular historic neighborhoods. It sets a scene that is usually envisaged as a mix between renovation and elements of historic Cairo. The second is the perception of the park as a more public venue, than offers open outreach to people, who otherwise might not be able or interested to join in. The park was later used several times for similar inaugurations of political campaigns and initiatives.

According to practices one witnesses in the park, and according to the initial plan of the park, it could hardly fit as a public space in the political ideal sense. It seems to be a relatively tamed public space, if it weren't for the daily and mundane practices of 'being' in the park, and negotiating to find the place in it where one belongs between the restaurants, the theatre, and the neighborhood. I wouldn't also argue that it is a dead public space [31], especially when the nature of similar public spaces in Cairo is taken into consideration. As has been commented, parks and spaces for recreation have never been really open to an undifferentiated public. They were usually catering to a very socially homogenous higher-class group looking for social exclusivity as a value, and the trend seems to unfortunately continue with increasing neo-liberal consumption places. As one interviewee would say: 'Many people from upper middle class or upper class believe being in a garden is boring, and would prefer going to cosmopolitan places like shopping malls, and hotels, places that are indoors and air-conditioned, where people go to show off.'

The case of Al-Azhar park is informative in several ways. Even though it is generally regarded as a very successful public space project, it raises a lot of questions for those seeking to problematize the possibility of chance encounters and difference in public spaces the city. It is also telling about how pervasive discourses of order and social predictability are and seem desirable in a city engulfed with discourses of exploding chaos: a concern that infiltrates the political discursive public sphere in Egypt.

\section{CONFLICT OF INTEREST}

The author confirms that this article content has no conflict of interest.

\section{ACKNOWLEDGEMENTS}

The idea of the paper and earlier draft was developed in a course I audited with professors Dr. Malak Rouchdy and Dr. Reem Saad in the American University in Cairo (Spring 2010). The idea was discussed with them and colleagues on the course. Audition of the course was made possible by a generous scholarship from Ford foundation in Cairo.

\section{REFERENCES}

[1] Elsheshtawy Y. Urban Transformations: social Control at al-Rifa“i Mosque and Sultan Hasan Square. In: Singerman D, Amar P. Eds. Cairo cosmopolitan: politics, culture, and urban space in the new globalized Middle East. Cairo etc.: The American University in Cairo Press 2006; pp. 295-312.

[2] Singerman D, Amar P, Eds. Cairo cosmopolitan: politics, culture, and urban space in the new globalized Middle East. Cairo, NewYork: The American University in Cairo Press 2006.

[3] Graghty B 2008. Great public spaces: Al-Azhar Park (CairoEgypt). Retrieved 2010 May 5. Available from: http://www.pps.org /great-public-spaces-al-azhar-park-cairo-egypt/,

[4] Mitchell D. The End of Public Space? People's Park, Definitions of the Public, and Democracy. Annals of the Association of American Geographers 1995; 85(1) :108-133. Available from: http://www.jst or.org/stable/2564281

[5] Arendt H. The Human Condition. Chicago and London: University of Chicago press 1998.

[6] Habermas J. (Burger T trans.). The structural transformation of the public sphere: an inquiry into a category of bourgeois society. Cambridge and Massachusetts: The MIT Press 1993.

[7] Benhabib S. Situating the self: gender, community and postmodernism in contemporary ethics. Cambridge: Polity Press 2007.

[8] Isin EF. Being political: genealogies of citizenship. University of Minnesota Press 2002

[9] Fraser N. Rethinking the public sphere: a contribution to the critique of actually existing democracy. Social Text 1990; (25/26): 56-80.

[10] Brickford S. Constructing inequality: city spaces and the architecture of citizenship. Polit Theory 2000; 28(3): 355-76.

[11] Weber M. (Martindale D, Neuwirth G trans.). The city. New York and London: The Free Press 1958.

[12] Weber M. The protestant ethic and the spirit of capitalism. London and New York: Routledge 2004.

[13] Young IM. City life as a normative ideal. In: Meagher SM, Ed. Philosophy and the city, Classic to contemporary writings. Albany: State University of New York Press 2008.

[14] Young IM. Inclusion and democracy. Oxford: Oxford University Press 2002.

[15] Zukin S. From landscapes of power. In: Bridge G, Watson S Eds. The Blackwell city reader. Blackwell Publishing 2008.

[16] Zieleniec A. Space and social theory. London: Sage Publications 2007.

[17] Ahmed HF. Pre-Colonial Modernity: The state and the making of the nineteenth-century Cairo's urban form. PhD dissertation. Berkeley: University of California 2001

[18] Raymond A. Cairo: city of history. The American University in Cairo Press 2007.

[19] Abu-Lughod J. Cairo: 1001 Years of the City Victorious. Princeton University Press 1971 .

[20] Battesti V. The Giza zoo: reappropriating public space, reimagining urban beauty. In: Singerman D, Amar P, Eds. Cairo cosmopolitan: politics, culture, and urban space in the new globalized Middle 
East. Cairo etc.: The American University in Cairo Press 2006; pp. 489-512.

[21] Abaza M. Shopping malls, consumer culture and the reshaping of public space in Egypt. Theor Cult Soc 2001; 18(5): 97-122.

[22] de Koning A. Café latte and Caesar salad: cosmopolitan belonging in Cairo's coffee shops. In: Singerman D, Amar P. Eds. Cairo cosmopolitan: politics, culture, and urban space in the new globalized Middle East. Cairo etc.: The American University in Cairo Press 2006; pp. 221-34.

[23] Adham K. Making or shaking the state: urban boundaries of state control and popular appropriation in Sayyida Zaynab model park. In: Singerman D. Cairo cosmopolitan: Governance, Urban Space and Global Modernity. Cairo: The American University in Cairo Press 2009.

[24] Krauss J. Green acres: in a concrete heavy city, landscapers hope Al-Azhar Park will help unearth a greener Cairo. Business today. August 2004. [Retrieved on May 15, 2011]. Available from http://www.businesstodayegypt.com/article.aspx?ArticleID=1440
[25] AKTC. Al-Azhar park, Cairo and the revitalization of Darb AlAhmar. Project Brief 2005.

[26] El-Essawi M. Une Décharge Devenue Jardin Public. In: Berthel P, Mondid S Eds. Le Caire: réinventer la ville. Paris Editions Autrement 2011.

[27] Campkin B, Cox R, Eds. Dirt- new geographies of cleanliness and contamination. London and New York I B Tauris 2007.

[28] http://www.youtube.com/watch?v=Z_QBD5pAqLY\&feature=player_e mbedded\#at=14 (Retrieved May 31, 2011).

[29] Khalaf R. No Music in the Park. Al Ahram Weekly. March $16^{\text {th }}$, 2006. [Retrieved May 31, 2011] Available from: http://www.maw red.org/images/stories/press/AlAhram-Weekly_16March.jpg

[30] El-Saket O. The shaabi music breakthrough. Egypt Independent. 20-10-2011. [Retrieved: March 1, 2012] Available from: http://egyptindependent.com/news/shaabi_music_breakthrough

[31] Sennet R. The fall of the public man. London: Penguin Books 2002.

Received: April 17, 2012

Revised: October 24, 2012

Accepted: February 6, 2013

(C) Aya Nassar; Licensee Bentham Open.

This is an open access article licensed under the terms of the Creative Commons Attribution Non-Commercial License (http://creativecommons.org/licenses/by$\mathrm{nc} / 3.0 /$ ) which permits unrestricted, non-commercial use, distribution and reproduction in any medium, provided the work is properly cited. 